ISSN 1392-3196 / e-ISSN 2335-8947

Zemdirbyste-Agriculture, vol. 100, No. 3 (2013), p. 283-288

DOI 10.13080/z-a.2013.100.036

\title{
The susceptibility of pea (Pisum sativum L.) to ascochyta blight under Lithuanian conditions
}

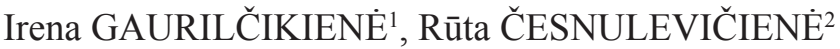 \\ ${ }^{1}$ Institute of Agriculture, Lithuanian Research Centre for Agriculture and Forestry \\ Instituto 1, Akademija, Kèdainiai distr., Lithuania \\ E-mail: irenag@1zi.lt \\ ${ }^{2}$ Perloja Experimental Station, Lithuanian Research Centre for Agriculture and Forestry \\ Sodo 12, Perloja, Varéna distr., Lithuania
}

\begin{abstract}
During the period 2008-2010, experiments were conducted to investigate the severity of ascochyta blight in the crops of semi-leafless field pea (Pisum sativum L.) cultivars 'Profi', 'Eiffel', 'Simona', 'Tinker', 'Mascara' and 'Pinochio' in different soil and climate conditions of Lithuania: 1) on a Southeast Luvisol (LV) in Perloja, 2) on a Middle Lowland's Cambisol (CM) in Dotnuva. The study was aimed to identify the susceptibility of various field pea cultivars to ascochyta blight under different agro-ecological conditions and to establish the effects of meteorological factors on the disease severity and to determine the composition of Ascochyta complex on pea plants.

In all experimental years, the values of area under disease progress curve (AUDPC) of ascochyta blight were higher in Perloja than in Dotnuva. Among the tested pea cultivars, 'Tinker' demonstrated the highest susceptibility to ascochyta blight, while 'Simona' and 'Pinochio' were less susceptible irrespective of the disease infection level. In Perloja, a significant moderate or strong correlation was identified between the AUDPC values of ascochyta blight and the amount of precipitation and sum of effective temperatures $\left(\sum \geq 5^{\circ} \mathrm{C}\right)$ for all field pea cultivars tested. Due to the low severity of ascochyta blight in Dotnuva, the interaction among the same factors was markedly lower. The incidence of ascochyta blight on pods was significantly influenced by the amount of precipitation in the second half of the growing season in both experimental sites, while only in Perloja it was also significantly influenced by effective temperatures. The frequency of detection of pathogens of Ascochyta complex on pea plants was high at pea seedling stage, later, until flowering, the frequency of pathogen detection diminished, and during the flowering-grain formation stage it increased again. In Dotnuva, at seedling stage and during the growing season Mycosphaerella pinodes and Phoma pinodella pathogens prevailed in the Ascochyta complex, and at the end of the growing season, Ascochyta pisi was prevalent on pods. In Perloja, the relative density of $A$. pisi in the population of Ascochyta complex was low during the entire growing season.
\end{abstract}

Key words: ascochyta blight, Ascochyta complex, meteorological factors, Pisum sativum.

\section{Introduction}

The field pea (Pisum sativum L.) is valued for protein-rich grain and for being a good pre-crop. In Lithuania, over the last decade, the field pea production area has fluctuated from 7.4 thousand ha in 2003 to 27.0 thousand ha in 2011 . The crop productivity varied significantly too: from $1.07 \mathrm{t} \mathrm{ha}^{-1}$ in 2006 to $2.0 \mathrm{t} \mathrm{ha}^{-1}$ in 2009. One of the reasons responsible for the low pea productivity is fungal diseases causing significant annual losses in grain yield (Garry et al., 1998; Beasse et al., 2000; Xue, 2000). More than 20 fungi species infesting pea crops have been established in various parts of the world. Ascochyta blight is widespread in all pea growing regions. Its causal agents are Ascochyta pisi, Mycosphaerella pinodes, Phoma pinodella, which are often referred to in literature as Ascochyta complex (Onfroy et al., 1999). These pathogens damage plant root, foot and aerial parts, pods and grains (Moussart et al., 1998; Bretag et al., 2006; Marcinkowska, 2008).

All three causal agents of ascochyta blight A. pisi, $M$. pinodes, $P$. pinodella are transmitted through infected seed and plant residues in the soil. Each of these pathogens causes specific symptoms on plants: $A$. pisi commonly causes leaf and pod spotting, $M$. pinodes and $P$. pinodella cause foot and root rots, and on aerial plant parts - stem, leaf and pod spotting (Wallen, 1974). A. pisi symptoms are circular, tan coloured with a dark brown margin, which differ from the multiple brown-purple spots caused by $M$. pinodes and P. pinodella (Bretag et al., 2006; Chilvers et al., 2009). However, the symptoms of the latter causal agents on the aerial plant part are very similar and difficult to differentiate even with the aid of molecular techniques (Faris-Mokaiesh et al., 1996; Onfroy et al., 1999; Wang et al., 2000). M. pinodes and $P$. pinodella infection persists very well on pea residues in the soil; however, the expression of $A$. pisi saprotrophic properties is weaker, therefore seed infection is more important for the spread of this pathogen (Bretag et al., 2006). The conidia of all pathogens of Ascochyta complex are dispersed by rain-splash in a crop within a short distance; however, $M$. pinodes ascospores are also 
wind-dispersed. The disease progression in a crop is significantly influenced by the plant architecture of the pea varieties and plant morphological peculiarities: leaf area and distribution, internode length, branching, stem strength and height (Le May et al., 2008; Schoeny et al., 2008). In Canada, where the pea cultivation area totals 1.3 million hectares, the yield losses from the diseases caused by Ascochyta complex amount to $50 \%$ and in separate years to $70 \%$ (Wallen, 1974; Xue, 2003). In France, research evidence has shown that in 7 years out of 10 pea grain yield losses from ascochyta blight ( $M$. pinodes) amounted to $20 \%$ (Beasse et al., 2000). Different pea pathogens differ in resistance to ascochyta blight; however, none of the existing varieties has exhibited complete resistance. Quantitative trait loci (QTL), influencing ascochyta blight resistance have been identified in a pea genome but molecular mechanism of resistance still has not been well ascertained (Onfroy et al., 1999; Wang et al., 2000; Timmerman-Vaughan et al., 2002; Prioul-Gervais et al., 2007). The susceptibility of Lithuania-grown pea cultivars to ascochyta blight is not known; moreover, there is no research evidence on this disease.

The current study was aimed: 1) to identify the susceptibility of various field pea cultivars to ascochyta blight under different agro-ecological conditions, 2) to establish the effect of meteorological factors on ascochyta blight infection and 3) to determine the composition of Ascochyta complex on pea plants.

\section{Materials and methods}

Determination of pea cultivar's susceptibility to ascochyta blight under different agro-ecological conditions. During the period 2008-2010, in different soil and climate conditions of Lithuania: 1) on Southeast's Luvisol (LV) in Perloja, 2) on Middle Lowland's Cambisol $(C M)$ in Dotnuva, experiments were conducted to investigate the severity of ascochyta blight in the crops of semi-leafless field pea cv. 'Profi', 'Eiffel', 'Simona', 'Tinker', 'Mascara' and 'Pinochio'. In the crops of the same cultivars, research was done into the detection frequency of the pathogens of Ascochyta complex on plants at different stages of their ontogenesis. In both experimental sites (Perloja and Dotnuva), experiments were sown using the same untreated seed at a rate of 1 million viable seeds $\mathrm{ha}^{-1}$, a conventional technology for pea cultivation for grain was employed. For all cultivars tested, $6 \times 24 \mathrm{~m}$ observation plots were formed in 6 metrewide bands, where from plant emergence to maturity, assessments of ascochyta blight severity were carried out periodically, every 14-18 days. For disease pressure assessment, three samples of 15 plants were formed from each cultivar's observation plot, phenological development stage was determined according to the BBCH scale (Weber, Bleiholder, 2001). Ascochyta blight severity on plants was estimated based on the diseaseaffected plant surface according to percentage scale, and ascochyta blight incidence on pods (percent of affected pods) was recorded (Sharma, 2004). The severity of ascochyta blight per season is expressed by the area under disease progress curve (AUDPC) value (Campbell, Madden, 1990).

Frequency of detection of pathogens of Ascochyta complex was investigated by cultivating fragments of plant parts on an oat agar medium (Dhingra, Sinclair, 1994; Roger, Tivoli, 1996 a). The pathogens of Ascochyta complex were identified according to the morphological traits typical of the colonies (Punithalingam, Holliday, 1972 a; b; Punithalingam, Gibson, 1976; Mathur, Kongsdal, 2003). Frequency of detection of Ascochyta complex pathogens and A. pisi relative density in Ascochyta complex were calculated (González et al., 1995).

Meteorological conditions. In 2008, in Dotnuva the sum of effective temperatures $\left(\sum \geq 5^{\circ} \mathrm{C}\right)$ was significantly higher than that in Perloja nearly throughout the whole growing season; however, the amount of rainfall was markedly higher in Perloja. In 2009, a slightly higher sum of effective temperatures since early spring was recorded in Dotnuva, while in summer months in Perloja. The year 2009 was distinguished by a droughty spring, especially in the Middle Lithuania zone. Later in the season, both experimental sites received a similar amount of rainfall, except for the downpour in Dotnuva, where $74 \mathrm{~mm}$ of rainfall fell within 4 hours on 23 June. In 2010, unlike in the previous year, there was more rainfall and rainy days in spring in Dotnuva; however, the first two ten-day periods of June and July were wetter in Perloja, except for third ten-day period of July when Dotnuva received as much as $101 \mathrm{~mm}$ more rainfall than Perloja. The effect of the meteorological factors - amount of precipitation $(\mathrm{mm})$ and sum of effective temperatures $\left(\sum \geq 5^{\circ} \mathrm{C}\right)$ on the severity of ascochyta blight in field pea were estimated by a binary regression and correlation data analysis method.

Statistical analysis. The experimental data were processed by the analysis of variance method. The significant difference of data was estimated according to Fisher and Duncan criteria. The method of binary regression and correlation analysis of data was used to estimate the interaction between AUDPC of ascochyta blight and environmental factors. Statistical analysis was done using the statistical data processing software package SELEKCIJA (software ANOVA, STAT) (Tarakanovas, Raudonius, 2003).

\section{Results and discussion}

The susceptibility of pea cultivars to ascochyta blight. In 2008, in Perloja the first symptoms of ascochyta blight were spotted in the crops of cv. 'Tinker' and 'Mascara' at stem elongation stage (BBCH 33-35), the lowest ascochyta blight severity at maturity stage was recorded for cv. 'Simona'. In Dotnuva, ascochyta blight appeared much later, the first disease symptoms on 'Profi' and 'Pinochio' plants were spotted only at flowering stage (BBCH 63), while on 'Simona' the disease occurred as late as seed ripening stage (BBCH 85) (Table 1). In 2009, in Perloja, ascochyta blight started to spread in pea crops at the end of bud formation stage, and by the beginning of flowering (BBCH 61-62) the disease had already severely spread in the crops of all cultivars. That year, significantly highest disease severity was identified for 'Mascara' and 'Tinker', while the lowest severity was measured for 'Simona' and 'Pinochio'. In Dotnuva, in 2009, the severity of ascochyta blight was markedly lower than that in Perloja, and the disease manifested itself more severely only at seed ripening stage (BBCH 83). The plants of cv. 'Profi' were most severely affected (Table 1). In 2010, both in Perloja and Dotnuva, ascochyta blight started to spread early, the first disease symptoms in the crops of all cultivars were spotted at stem elongation stage $(\mathrm{BBCH}$ 36-37). The disease severity until beginning of flowering (BBCH 61) was low; later, at grain-formation stage 
(BBCH 79), in Perloja ascochyta blight significantly more severely affected 'Tinker', while 'Simona' plants were least affected. In Dotnuva also the highest ascochyta blight severity was identified on 'Tinker' pea plants, the disease progressed more slowly in the crops of cv. 'Pinochio', 'Mascara' and 'Simona' (Table 1).

Table 1. The severity of ascochyta blight (\%) on the field pea cultivars in Perloja and Dotnuva

\begin{tabular}{|c|c|c|c|c|c|c|c|c|c|c|c|}
\hline \multirow{3}{*}{ Cultivar } & \multicolumn{6}{|c|}{ Perloja } & \multicolumn{5}{|c|}{ Dotnuva } \\
\hline & \multicolumn{11}{|c|}{2008} \\
\hline & $\mathrm{BBCH}$ & $33-35^{*}$ & $51-55$ & 65-69 & $75-77$ & $84-85$ & $52-55$ & 61 & 63 & 75 & 85 \\
\hline 'Profi' & & $0 \mathrm{a}$ & $2.6 \mathrm{c}$ & $2.7 \mathrm{a}$ & $3.4 \mathrm{a}$ & $5.0 \mathrm{ab}$ & 0 & 0 & $0.07 \mathrm{c}$ & $0.3 \mathrm{bcd}$ & $4.6 \mathrm{~b}$ \\
\hline 'Eiffel' & & $0 \mathrm{a}$ & $3.8 \mathrm{~d}$ & $5.5 \mathrm{c}$ & $5.6 \mathrm{~cd}$ & $5.8 \mathrm{ab}$ & 0 & 0 & $0 \mathrm{a}$ & $0.4 \mathrm{~d}$ & $3.2 \mathrm{a}$ \\
\hline Simona & & $0 \mathrm{a}$ & $1.2 \mathrm{ab}$ & $3.0 \mathrm{a}$ & $3.3 \mathrm{a}$ & $3.8 \mathrm{a}$ & 0 & 0 & $0 \mathrm{a}$ & $0 \mathrm{a}$ & $2.5 \mathrm{a}$ \\
\hline 'Tinker' & & $4.6 \mathrm{c}$ & $5.1 \mathrm{e}$ & $3.0 \mathrm{a}$ & $6.0 \mathrm{~cd}$ & $7.0 \mathrm{c}$ & 0 & 0 & $0 \mathrm{a}$ & $0.1 \mathrm{ab}$ & $3.5 \mathrm{a}$ \\
\hline 'Mascara' & & $2.3 \mathrm{~b}$ & $1.8 \mathrm{bc}$ & $2.2 \mathrm{a}$ & $6.1 \mathrm{~d}$ & $6.8 \mathrm{bc}$ & 0 & 0 & $0 \mathrm{a}$ & $0.07 \mathrm{a}$ & $1.9 \mathrm{a}$ \\
\hline \multirow[t]{3}{*}{ 'Pinochio' } & & $0 \mathrm{a}$ & $0.4 \mathrm{a}$ & $4.9 \mathrm{c}$ & $3.9 \mathrm{ab}$ & $4.3 \mathrm{a}$ & 0 & 0 & $0.03 \mathrm{ab}$ & $0.1 \mathrm{ab}$ & $2.7 \mathrm{a}$ \\
\hline & \multicolumn{11}{|c|}{2009} \\
\hline & $\mathrm{BBCH}$ & 36 & 51 & $61-62$ & 79 & $84-85$ & 51 & $61-62$ & 71 & $77-79$ & 83 \\
\hline 'Profi' & & 0 & 0 & $14.2 \mathrm{e}$ & $15.3 \mathrm{bc}$ & $15.9 \mathrm{ab}$ & 0 & $0.03 \mathrm{a}$ & $0.9 \mathrm{bc}$ & $2.6 \mathrm{c}$ & $13.2 \mathrm{c}$ \\
\hline 'Eiffel' & & 0 & 0 & $10.3 \mathrm{bc}$ & $15.5 \mathrm{c}$ & $16.0 \mathrm{abcd}$ & 0 & $0.2 \mathrm{a}$ & $0.7 \mathrm{abc}$ & $2.0 \mathrm{bc}$ & $6.2 \mathrm{a}$ \\
\hline 'Simona' & & 0 & 0 & 13.7 cde & $14.7 \mathrm{abc}$ & $14.7 \mathrm{a}$ & 0 & $0.03 \mathrm{a}$ & $0.4 \mathrm{a}$ & $1.9 \mathrm{bc}$ & $3.8 \mathrm{a}$ \\
\hline 'Tinker' & & 0 & 0 & $10.0 \mathrm{bc}$ & $15.0 \mathrm{bc}$ & $17.0 \mathrm{bcd}$ & 0 & $0.2 \mathrm{a}$ & $0.6 \mathrm{abc}$ & $2.0 \mathrm{bc}$ & $7.3 \mathrm{abc}$ \\
\hline 'Mascara' & & 0 & 0 & $8.3 \mathrm{~b}$ & $14.0 \mathrm{a}$ & $17.5 \mathrm{~d}$ & 0 & $0.2 \mathrm{a}$ & $0.6 \mathrm{abc}$ & $0.8 \mathrm{a}$ & $6.1 \mathrm{a}$ \\
\hline \multirow[t]{3}{*}{ 'Pinochio' } & & 0 & 0 & $2.4 \mathrm{a}$ & $14.8 \mathrm{bc}$ & $14.8 \mathrm{a}$ & 0 & $0 \mathrm{a}$ & $0.9 \mathrm{c}$ & $1.5 \mathrm{abc}$ & $9.2 \mathrm{abc}$ \\
\hline & \multicolumn{11}{|c|}{2010} \\
\hline & $\mathrm{BBCH}$ & $36-37$ & $54-55$ & $61-63$ & 79 & $84-85$ & 36 & 39 & 61 & 79 & $84-85$ \\
\hline 'Profi' & & $1.0 \mathrm{c}$ & $2.3 \mathrm{a}$ & $8.1 \mathrm{~d}$ & $20.0 \mathrm{bc}$ & $30.8 \mathrm{~b}$ & $1.6 \mathrm{~b}$ & $2.3 \mathrm{c}$ & $2.7 \mathrm{a}$ & $4.7 \mathrm{~cd}$ & $3.4 \mathrm{a}$ \\
\hline 'Eiffel' & & $0.7 \mathrm{~b}$ & $5.0 \mathrm{~cd}$ & $5.3 \mathrm{a}$ & $21.0 \mathrm{bc}$ & $31.4 \mathrm{bc}$ & $0.6 \mathrm{a}$ & $1.3 \mathrm{a}$ & $1.6 \mathrm{a}$ & $5.2 \mathrm{~cd}$ & $3.9 \mathrm{a}$ \\
\hline 'Simona' & & $0.8 \mathrm{~b}$ & $2.3 \mathrm{a}$ & $6.6 \mathrm{~cd}$ & $18.5 \mathrm{a}$ & $24.3 \mathrm{a}$ & $0.9 \mathrm{a}$ & $1.1 \mathrm{a}$ & $3.1 \mathrm{a}$ & $3.1 \mathrm{ab}$ & $4.5 \mathrm{a}$ \\
\hline 'Tinker' & & $1.3 \mathrm{~d}$ & $6.0 \mathrm{~d}$ & $7.0 \mathrm{~cd}$ & $28.0 \mathrm{c}$ & $40.2 \mathrm{~d}$ & $6.0 \mathrm{c}$ & $2.7 \mathrm{c}$ & $7.3 \mathrm{~b}$ & $5.8 \mathrm{~d}$ & $5.0 \mathrm{~b}$ \\
\hline 'Mascara' & & $0.03 \mathrm{a}$ & $2.1 \mathrm{a}$ & $6.1 \mathrm{ab}$ & $18.0 \mathrm{a}$ & $30.0 \mathrm{~b}$ & $0.2 \mathrm{a}$ & $1.4 \mathrm{a}$ & $1.6 \mathrm{a}$ & $2.4 \mathrm{a}$ & $4.4 \mathrm{a}$ \\
\hline 'Pinochio' & & $0.1 \mathrm{a}$ & $3.0 \mathrm{ab}$ & $5.6 \mathrm{ab}$ & $26.0 \mathrm{bc}$ & $35.1 \mathrm{bc}$ & $0.7 \mathrm{a}$ & $1.3 \mathrm{a}$ & $1.5 \mathrm{a}$ & $1.9 \mathrm{a}$ & $3.9 \mathrm{a}$ \\
\hline
\end{tabular}

Note. The values denoted by the same letter in the same site and year did not differ significantly $(P \leq 0.05)$.

The disease severity was particularly significantly influenced by the experimental site's agroecological conditions. In all experimental years, the AUDPC values of ascochyta blight were higher in Perloja than those in Dotnuva (Table 2). The AUDPC values of the disease were the highest for cv. 'Tinker' in Perloja and for 'Profi' in Dotnuva for two years out of three, while for 'Simona' these values were the lowest. The AUDPC values of ascochyta blight for the other cultivars tested varied markedly between years and experimental sites. The data of the experiments carried out for three years in different agro-climatic conditions showed 'Tinker' to be more susceptible to ascochyta blight, while cv. 'Simona' and 'Pinochio' were less susceptible.

Table 2. The area under disease progress curve (AUDPC) values of ascochyta blight on the field pea cultivars in Perloja and Dotnuva

\begin{tabular}{cccc|ccc}
\hline \multirow{2}{*}{ Cultivar } & \multicolumn{3}{c}{ Perloja } & \multicolumn{3}{c}{ Dotnuva } \\
\cline { 2 - 7 } & 2008 & 2009 & 2010 & 2008 & 2009 & 2010 \\
\hline 'Profi' & $99 \mathrm{ab}$ & $271 \mathrm{c}$ & $455 \mathrm{ab}$ & $37 \mathrm{c}$ & $132 \mathrm{c}$ & $102 \mathrm{c}$ \\
'Eiffel' & $152 \mathrm{~cd}$ & $257 \mathrm{bc}$ & $463 \mathrm{ab}$ & $27 \mathrm{abc}$ & $70 \mathrm{ab}$ & $92 \mathrm{bc}$ \\
'Simona' & $83 \mathrm{a}$ & $253 \mathrm{bc}$ & $385 \mathrm{a}$ & $19 \mathrm{a}$ & $48 \mathrm{a}$ & $90 \mathrm{bc}$ \\
'Tinker' & $169 \mathrm{~d}$ & $260 \mathrm{bc}$ & $601 \mathrm{~d}$ & $27 \mathrm{abc}$ & $78 \mathrm{ab}$ & $175 \mathrm{~d}$ \\
'Mascara' & $133 \mathrm{bcd}$ & $251 \mathrm{bc}$ & $414 \mathrm{ab}$ & $15 \mathrm{a}$ & $59 \mathrm{ab}$ & $72 \mathrm{ab}$ \\
'Pinochio' & $100 \mathrm{ab}$ & $216 \mathrm{a}$ & $516 \mathrm{bcd}$ & $21 \mathrm{a}$ & $91 \mathrm{~b}$ & $65 \mathrm{a}$ \\
\hline
\end{tabular}

Explanation under Table 1

The incidence of ascochyta blight on the pods of the pea cultivars tested was observed in all experimental years. In 2008, the pods of cv. 'Simona' and 'Pinochio' were free from ascochyta blight in both experimental sites (Table 3). In 2009, lower disease pressure was noted on the pods of 'Pinochio' (73.3\%) in Perloja, in Dotnuva on the pods of 'Tinker' (66.7\%). In 2010, in Perloja ascochyta blight incidence on pods was as high as $95.0-100 \%$, in Dotnuva 70.0-95.0\%.

The effect of the meteorological factors on the severity of ascochyta blight in field pea crops. A combination of three factors is necessary for the spread of fungal diseases: pathogen - host plant - favourable environmental conditions (Van der Plank, 1963). In our study, in both experimental sites (Perloja and Dotnuva) the first two factors were similar; however, there were annual differences in the meteorological conditions (air temperature, precipitation rate as well as the number of rainy days) between the sites (Dotnuva-Middle and Perloja-Southeast Lithuania). Because of the differences in the environmental parameters between the sites the incidence of pea ascochyta blight was uneven. To estimate the effects of the amount of precipitation and the sum of effective temperatures $\left(\sum \geq 5^{\circ} \mathrm{C}\right)$ on the AUDPC values of ascochyta blight, a binary regression correlation analysis of data was conducted. A strong 
Table 3. The incidence of ascochyta blight on pea pods (\%) in Perloja and Dotnuva

\begin{tabular}{cccc|ccc}
\hline \multirow{2}{*}{ Cultivar } & \multicolumn{3}{c|}{ Perloja } & \multicolumn{3}{c}{ Dotnuva } \\
\cline { 2 - 7 } & 2008 & 2009 & 2010 & 2008 & 2009 & 2010 \\
\hline 'Profi' & $36.7 \mathrm{e}$ & $100 \mathrm{~d}$ & $98.0 \mathrm{a}$ & $13.0 \mathrm{~b}$ & $76.7 \mathrm{abcd}$ & $70.0 \mathrm{a}$ \\
'Eiffel' & $20.0 \mathrm{c}$ & $100 \mathrm{~d}$ & $98.2 \mathrm{a}$ & $20.0 \mathrm{c}$ & $80.0 \mathrm{abcd}$ & $75.0 \mathrm{a}$ \\
'Simona' & $0 \mathrm{a}$ & $96.7 \mathrm{bcd}$ & $90.0 \mathrm{a}$ & $0 \mathrm{a}$ & $96.7 \mathrm{~d}$ & $90.0 \mathrm{bcd}$ \\
'Tinker' & $13.3 \mathrm{~b}$ & $100 \mathrm{~d}$ & $100 \mathrm{a}$ & $13.3 \mathrm{~b}$ & $66.7 \mathrm{a}$ & $95.0 \mathrm{~d}$ \\
'Mascara' & $26.7 \mathrm{~d}$ & $90.0 \mathrm{bc}$ & $96.7 \mathrm{a}$ & $33.3 \mathrm{~d}$ & $93.3 \mathrm{bcd}$ & $80.0 \mathrm{ab}$ \\
'Pinochio' & $0 \mathrm{a}$ & $73.3 \mathrm{a}$ & $95.0 \mathrm{a}$ & $0 \mathrm{a}$ & $70.0 \mathrm{ab}$ & $90.0 \mathrm{bcd}$ \\
\hline
\end{tabular}

Explanation under Table 1

significant correlation $(P \leq 0.01)$ was established among the AUDPC values of pea ascochyta blight and the sum of effective temperatures during the growing season and the amount of precipitation in the second half of the growing season for all pea cultivars in Perloja (Table 4). However, in Dotnuva, the correlation among the same factors was considerably weaker. A significant strong correlation between the AUDPC values of ascochyta blight and the amount of precipitation in the second half of the growing season was established only for 'Profi' and 'Pinochio'. The correlation of the AUDPC values of ascochyta blight and the sum of effective temperatures was moderate for the same cultivars. In Dotnuva, in the crops of other cultivars, meteorological indicators correlated with ascochyta blight weakly or did not correlate at all. It is likely that such results were obtained because of the low severity of ascochyta blight in Dotnuva, compared with Perloja, where the disease severity was markedly higher. Ascochyta blight incidence on pods was significantly influenced both in Dotnuva and Perloja by the amount of precipitation in the second half of the growing season (from $r=0.80$ to $r=0.99$ ), and in Perloja also by effective temperatures, from $r=0.70$ to $r=0.87$.

Table 4. The correlation coefficients $(r)$ among the area under disease progress curve (AUDPC) values of ascochyta blight and the amount of precipitation $(\mathrm{mm})$ and the sum of effective temperatures $\left(\sum \mathrm{T} \geq 5^{\circ} \mathrm{C}\right) 2008-2010$

\begin{tabular}{|c|c|c|c|c|c|c|}
\hline \multirow{2}{*}{ Environmental indicators } & \multicolumn{6}{|c|}{ Cultivar } \\
\hline & 'Profi' & 'Eiffel' & 'Simona' & 'Tinker' & 'Mascara' & 'Pinochio' \\
\hline \multicolumn{7}{|c|}{$r$ between AUDPC of ascochyta blight and environmental indicators } \\
\hline \multicolumn{7}{|c|}{ Dotnuva } \\
\hline Precipitation $2104-3105$ & 0.40 & 0.10 & 0.44 & 0.01 & 0.14 & 0.19 \\
\hline Precipitation $0106-2107$ & $0.90 * *$ & 0.56 & 0.09 & 0.62 & 0.46 & $0.92 * *$ \\
\hline$\sum \mathrm{T} \geq 5^{\circ} \mathrm{C} 2104-3105$ & 0.54 & 0.46 & 0.44 & 0.55 & 0.55 & $0.73 *$ \\
\hline$\sum \mathrm{T} \geq 5^{\circ} \mathrm{C} 0106-2107$ & $0.70 *$ & 0.32 & 0.29 & 0.28 & 0.10 & 0.55 \\
\hline \multicolumn{7}{|c|}{ Perloja } \\
\hline Precipitation $2104-3105$ & 0.66 & $0.68 *$ & 0.56 & $0.73^{*}$ & 0.63 & $0.71 *$ \\
\hline Precipitation $0106-2107$ & $0.80 * *$ & $0.79 *$ & $0.87 * *$ & $0.69^{*}$ & $0.83 * *$ & $0.73 *$ \\
\hline$\sum \mathrm{T} \geq 5^{\circ} \mathrm{C} 2104-3105$ & $0.91 * *$ & $0.99 * *$ & $0.99 * *$ & $0.94 * *$ & $0.99 * *$ & $0.96 * *$ \\
\hline$\sum \mathrm{T} \geq 5^{\circ} \mathrm{C} 0106-2107$ & $0.99 * *$ & $0.99 * *$ & $0.97 * *$ & $0.96 * *$ & $0.99 * *$ & $0.97 * *$ \\
\hline \multicolumn{7}{|c|}{$r$ between ascochyta blight severity on pods and environmental indicators } \\
\hline \multicolumn{7}{|c|}{ Dotnuva } \\
\hline Precipitation $0106-3107$ & $0.84 * *$ & $0.98^{* *}$ & $0.97 * *$ & $0.80^{*}$ & $0.96^{* *}$ & $0.88^{* *}$ \\
\hline$\sum \mathrm{T} \geq 5^{\circ} \mathrm{C} 0106-3107$ & 0.47 & 0.48 & 0.49 & 0.43 & 0.46 & 0.47 \\
\hline \multicolumn{7}{|c|}{ Perloja } \\
\hline Precipitation $0106-3107$ & $0.99 * *$ & $0.99 * *$ & $0.99 * *$ & $0.99 * *$ & $0.97 * *$ & $0.97 * *$ \\
\hline$\sum \mathrm{T} \geq 5^{\circ} \mathrm{C} 0106-3107$ & $0.73 *$ & $0.74 *$ & $0.70 *$ & $0.75 *$ & $0.78 *$ & $0.87 * *$ \\
\hline
\end{tabular}

Number of pairs: in $2008 \mathrm{n}=9$, in $2009 \mathrm{n}=9$, in $2010 \mathrm{n}=9 ; *_{-} P \leq 0.05, * *_{-} P \leq 0.01$

The conidia of the pathogens of Ascochyta complex are dispersed by rain-splash onto other plants horizontally and upwards to the newly emerging plant parts (Roger, Tivoli, 1996 b; Schoeny et al., 2008). A minimum wet period of $2 \mathrm{~h}$ is required for the germination of $M$. pinodes conidia at temperatures from $15^{\circ} \mathrm{C}$ to $30^{\circ} \mathrm{C}$. The pathogenic conidia that have been dispersed to newly emerging plant parts can survive dry periods of up to 21 days and can successfully germinate after the rain. Roger et al. (1999) indicated that ascochyta blight infection was severe in each case when plants were returned to wet conditions after a period of dryness. Setti et al. (2008) reported that lengthening of the duration of wet period increased ascochyta blight severity in the crops of all pea varieties tested. Moreover, the authors maintain that a 48-hour period of uninterrupted wetness on plants in the crops susceptible to ascochyta blight stipulated the outbreak of infection and is an indicator for use of fungicides.
Frequency of detection of the pathogens of Ascochyta complex on field peas. Pathogens of the Ascochyta complex were abundantly detected on pea seedlings in both experimental sites. It is likely that the major source of pathogens isolated at an early growth stage was seed-borne infection. All pathogens of the Ascochyta complex are seed-borne; $M$. pinodes and $P$. pinodella can cause root and foot rots, while first symptoms of $A$. pisi appear on a stemlet above the first leaves (Bretag et al., 2006). Later, with rapid growth of plants, until flowering stage, the frequency of detection of pathogens of Ascochyta complex diminished, and during flowering-grain formation stage the detection frequency rapidly increased until maturity stage (Table 5).

Both in Dotnuva and Perloja, the frequency of pathogen detection on individual varieties varied appreciably at different growth stages. For the similarity of cultural indications of Mycosphaerella pinodes and Phoma pinodella, these pathogens were not separated and 
Table 5. The frequency of detection of Ascochyta complex and the relative density of A. pisi in Ascochyta complex on pea plants of six cultivars at different plant growth stages $(\mathrm{BBCH})$ in Dotnuva and Perloja (standard deviation rate is given)

\begin{tabular}{ccccccc}
\hline Year / site & \multicolumn{5}{c}{ BB pods } \\
\cline { 2 - 6 }$(\mathrm{BBCH} 83)$ \\
\hline
\end{tabular}

relative density in Ascochyta complex only for Ascochyta pisi was calculated. In Dotnuva, at seedling stage and during the growing season $M$. pinodes and P. pinodella patogens prevailed in the Ascochyta complex, and at the end of the growing season, $A$. pisi was prevalent on pods. In Perloja, the relative density of $A$. pisi in the population of Ascochyta complex was low during the entire growing season. Until grain-formation stage, only solitary isolates of $A$. pisi were detected. At maturity stage, the highest relative density of this pathogen in the Ascochyta complex was identified on the stems of 'Tinker' and 'Mascara'. There was found no consistent relationship between the frequency of detection of pathogens and pea cultivar.

\section{Conclusions}

1. The pea cv. 'Tinker' demonstrated the highest susceptibility to ascochyta blight, while 'Simona' and 'Pinochio' were less susceptible irrespective of the ascochyta blight infection level.

2. In Perloja, a significant moderate or strong correlation was identified between the area under disease progress curve (AUDPC) values of pea ascochyta blight and the amount of precipitation and sum of effective temperatures $\left(\sum \mathrm{T} \geq 5^{\circ} \mathrm{C}\right)$ for all field pea cultivars tested. Due to the low severity of ascochyta blight in Dotnuva, the interaction among the same factors was markedly lower. The incidence of ascochyta blight on pods was significantly influenced by the amount of precipitation in the second half of the growing season (from $r=0.80$ to $r=0.98$ and $r=0.97$ to $r=0.99$ for individual cultivars, respectively) in both experimental sites, while only in Perloja it was also significantly influenced by effective temperatures (from $r=0.70$ to $r=0.87$ ).

3. The frequency of detection of pathogens of Ascochyta complex was high at pea seedling stage, later, until flowering, the frequency of pathogen detection diminished, and during the flowering-grain formation stage it increased again. The pods of all varieties were severely infected with the pathogens of Ascochyta complex, among which $A$. pisi took the dominant position in Dotnuva; however, in Perloja the complex of Mycosphaerella pinodes and Phoma pinodella previled.

\section{Acknowledgements}

The paper presents research findings, obtained through the long-term research programme "Harmful organisms in agro and forest ecosystems" implemented by Lithuanian Research Centre for Agriculture and Forestry.

Received 31122012

Accepted 15052013

\section{References}

Beasse C., Ney B., Tivoli B. 2000. A simple model of pea (Pisum sativum) growth affected by Mycosphaerella pinodes. Plant Pathology, 49: 187-200

Bretag T. W., Keane P. J., Price T. V. 2006. The epidemiology and control of Ascochyta blight in field peas: a review. Australian Journal of Agricultural Research, 57 (8): 883$902 \mathrm{http} / / / \mathrm{dx}$. doi.org/10.1071/AR05222

Campbell C. L., Madden L. V. 1990. Temporal analysis of epidemics. I. Description and comparison of diseases progress curves. Campbell C. L., Madden L. V. (eds). Introduction to Plant Disease Epidemiology, p. 161-202

Chilvers M. I., Rogers J. D., Dugan F. M., Stewart J. E., Chen W., Peever T. L. 2009. Didymella pisi sp. nov., the teleomorph of Ascochvta pisi. Mvcological Research. 113: 391-400 http://dx.doi.org/10.1016/j.mycres.2008.11.017

Dhingra O. D., Sinclair J. B. 1994. Basic plant pathology methods

Faris-Mokaiesh S., Boccara M., Denis J.-B., Derrien A., Spire D. 1996. Differentiation of the Ascochyta complex fungi of pea by biochemical and molecular markers. Current Genetics, 29 (2): 182-190 http://dx.doi.org/10.1007/BF02221583

Garry G., Jeuffroy M. H., Ney B., Tivoli B. 1998. Effects of Ascochyta blight (Mycosphaerella pinodes) on the photosynthesizing leaf area and the photosynthetic efficiency of the green leaf area of dried-pea. Plant Pathology, 47: 473479 http://dx.doi.org/10.1046/j.1365-3059.1998.00259.x

González H. H. L., Resnik S. L., Boca R. T., Marasas W. F. O. 1995. Mycoflora of Argentinean corn harvested in the main production area in 1990. Mycopathologia, 130: 29 $36 \mathrm{http}: / / \mathrm{dx}$. doi.org/10.1007/BF01104346

Le May C., Ney B., Lemarchand E., Schoeny A., Tivoli B. 2008. Effect of pea plant architecture on spatiotemporal epidemic development of Ascochyta blight (Mycosphaerella pinodes) in the field. Plant Pathology, 58 (2): 332-343 http://dx.doi.org/10.1111/j.1365-3059.2008.01947.x

Marcinkowska J. 2008. Fungi occurrence on seed of field pea. Acta Mycologica, 43 (1): 77-89

Mathur S. B., Kongsdal O. 2003. Common laboratory seed health testing methods for detecting fungi ( $3^{\text {rd }}$ ed.)

Moussart A., Tivoli B., Lemarchand E., Deneufbourg F., Roi S. Sicard G. 1998. Role of seed infection by the Ascochyta blight pathogen of dried pea (Mycosphaerella pinodes) in seeding emergence, early disease development and transmission of the disease to aerial plant parts. European Journal of Plant Pathologv. 104: 93-102 http://dx.doi.org/10.1023/A:1008673914537

Onfroy C., Tivoli B., Corbiere R., Bouznad Z. 1999. Cultural, molecular and pathogenic variability of Mycosphaerella pinodes and Phoma medicaginis var. pinodella isolates from dried nea (Pisum sativum) in France. Plant Pathology. 48:218 229 http://dx.doi.org/10.1046/j.1365-3059.1999.00323.x

Prioul-Gervais S., Deniot G., Receveur E. M., Frankewitz A., Fourmann M., Rameau C., Pilet-Nayel M. L., Baranger A. 2007. Candidate genes for quantitative resistance to Mycosphaerella pinodes in pea (Pisum sativum L.). Theoretical and Applied Genetics. 114 (6): 971-984 http://dx.doi.org/10.1007/s00122-006-0492-y 
Punithalingam E., Holliday P. 1972 (a). Ascochyta pisi. CMI Description of Pathogenic Fungi No. 334

Punithalingam E., Holliday P. 1972 (b). Mycosphaerella pinodes. CMI Description of Pathogenic Fungi No. 340

Punithalingam E., Gibson I. A. S. 1976. Phoma medicaginis var. pinodella. CMI Description of Pathogenic Fungi No. 518

Roger C., Tivoli B. 1996 (a). Effects of culture medium, light and temperature on sexual and asexual reproduction of four strains of Mycosphaerella pinodes. Mycological Research, 100 (3): 304-306

http://dx.doi.org/10.1016/S0953-7562(96)80159-6

Roger C., Tivoli B. 1996 (b). Spatio-temporal development of pycnidia and perithecia and dissemination of spores of Mycosphaerella pinodes on pea (Pisum sativum). Plant Pathologv. 45: 518-528 http://dx.doi.org/10.1046/j.1365-3059.1996.d01-139.x

Roger C., Tivoli B., Huber L. 1999. Effects of interrupted wet periods and different temperatures on the development of Ascochyta blight caused by Mycosphaerella pinodes on pea (Pisum sativum) seedlings. Plant Pathologv. 48: 10-18 http://dx.doi.org/10.1046/j.1365-3059.1999.00311.x

Schoeny A., Menat J., Darsonval A., Rouault F., Jumel S., Tivoli B. 2008. Effect of pea canopy architecture on splash dispersal of Mycosphaerella pinodes conidia. Plant Pathology. 57: 1073-1085 http://dx.doi.org/10.1111/j.1365-3059.2008.01888.x

Setti B., Bencheikh M., Henni J. E., Neema C. 2008. Effect of pea cultivar, pathogen isolate, inoculum concentration and leaf wetness duration on Ascochyta blight caused by Mycosphaerella pinodes. Phytopathologia Mediterrana, 47: 214-222

Sharma P. D. 2004. Epidemiology, assessments and forecasting of plant diseases. Sharma P. D. (ed.). Plant Pathology, p. 91-102
Tarakanovas P., Raudonius S. 2003. Agronominiu tyrimu duomenų statistinè analizè taikant kompiuterines programas ANOVA, STAT, SPLIT-PLOT iš paketo SELEKCIJA ir IRRISTAT. Lithuanian University of Agriculture, $58 \mathrm{p}$. (in Lithuanian)

Timmerman-Vaughan G. M., Frew T. J., Russell A. C., Khan T., Butler R., Gilpin M., Murray S., Falloon K. 2002. QTL mapping of partial resistance to field epidemics of Ascochyta blight of nea. Cron Science, 42: 2100-2111 http://dx.doi.org/10.2135/cropsci2002.2100

Van der Plank J. E. 1963. Plant diseases: epidemics and control

Wallen V. R. 1974. Influence of three Ascochyta diseases of peas on the development and yield. Canadian Plant Disease Survey, Disease Highlights, 54: 86-90

Wang H., Hwang S. F., Chang K. F., Turnbull G. D., Howard R. J. 2000. Characterization of Ascochyta isolates and susceptibility of pea cultivars to the Ascochyta disease complex in Alberta. Plant Pathology, 49: 540-545 http://dx.doi.org/10.1046/j.1365-3059.2000.00489.x

Weber E., Bleiholder H. 2001. Phenological growth stages and $\mathrm{BBCH}$-identification keys of pea (Pisum sativum). Meier U. (ed.). Growth sages of mono- and dicotyledonous plants. BBCH Monograph ( $2^{\text {nd }}$ ed.), p. 138-140. < http:// www.jki.bund.de/fileadmin/dam uploads/ veroeff/bbch/ BBCH-Skala_englisch.pdf $>$ [accessed $100 \overline{4}$ 2013]

Xue A. G. 2000. Effect of seed-borne Mycosphaerella pinodes and seed treatments on emergence foot rot severity, and yield of field pea. Canadian Journal of Plant Pathology. 22 (3): 248-253 http://dx.doi.org/10.1080/07060660009500471

Xue A. G. 2003. Efficacy of Clonostachys rosea strain ACM941 and fungicide seed treatments for controlling the root rot complex of field pea. Canadian Journal of Plant Science, 83: 519-524 http://dx.doi.org/10.4141/P02-078

ISSN 1392-3196 / e-ISSN 2335-8947

Zemdirbyste-Agriculture, vol. 100, No. 3 (2013), p. 283-288

DOI 10.13080/z-a.2013.100.036

\title{
Sẻjamojo žirnio (Pisum sativum L.) jautrumas askochitozei Lietuvos sąlygomis
}

\author{
I. Gaurilčikiené $\dot{1}^{1}, \mathrm{R}$. Česnulevičiené ${ }^{2}$
}

${ }^{1}$ Lietuvos agrarinių ir miškų mokslų centro Žemdirbystès institutas

${ }^{2}$ Lietuvos agrarinių ir miškų mokslų centro Perlojos bandymų stotis

\section{Santrauka}

2008-2010 m. skirtingomis dirvos ir klimato sąlygomis: 1) išplautžemyje (ID) Pietryčiu Lietuvoje Perlojoje ir 2) rudžemyje (RD) Vidurio Lietuvoje Dotnuvoje tirta askochitozės intensyvumas sèjamojo žirnio (Pisum sativum L.) pusiau belapių veisliu 'Profi', 'Eiffel', 'Simona', 'Tinker', 'Mascara' ir 'Pinochio' pasèliuose. Tyrimų metu siekta nustatyti sèjamojo žirnio veisliu jautrumą askochitozei skirtingomis agroekologinėmis sąlygomis, ịvertinti meterologinių veiksnių įtaką ligos intensyvumui ir nustatyti Ascochyta komplekso patogenų struktūrą ant žirniu augalu.

Visais tyrimų metais askochitozès AUDPC (angl. area under disease progress curve ,plotas po ligos vystymosi per vegetaciją kreive") reikšmès buvo didesnès Perlojoje nei Dotnuvoje. Nepriklausomai nuo askochitozės infekcijos smarkumo, ligai jautriausi buvo veislès 'Tinker', mažiau jautrūs - veislių 'Simona' ir 'Pinochio' žirniai. Perlojoje nustatytas visų žirnių veislių esminis vidutinis arba stiprus koreliacinis ryšys tarp žirnių askochitozès AUDPC reikšmių ir kritulių kiekio bei efektyvių temperatūrų sumos $\left(\sum T \geq 5^{\circ}\right)$. Dèl nedidelio askochitozès intensyvumo Dotnuvoje tų pačiu veiksnių sąveika buvo gerokai silpnesnè. Askochitozės išplitimą ant ankščių ir Dotnuvoje, ir Perlojoje iš esmès lëmè kritulių kiekis antroje vegetacijos pusëje, o Perlojoje - ir efektyvios temperatūros. Ascochyta komplekso patogenai ant visų veislių žirnių buvo gausiai aptinkami daigų tarpsniu, vèliau iki žydèjimo tarpsnio patogenu aptikimo dažnis mažèjo, o žydejjimo-grūdo formavimosi tarpsniu vèl padidèjo. Daigų tarpsniu ir vegetacijos metu Dotnuvoje Ascochyta komplekse vyravo Mycosphaerella pinodes ir Phoma pinodella patogenai, o vegetacijos pabaigoje ant ankščiu - Ascochyta pisi. Perlojoje A. pisi santykinis tankis Ascochyta komplekso populiacijoje buvo mažas visos vegetacijos metu. Nuoseklios patogenų aptikimo dažnio nuo žirnių veislès priklausomybès nenustatyta.

Reikšminiai žodžiai: Ascochyta kompleksas, meterologinės sąlygos, Pisum sativum, žirnių askochitozès. 